\title{
Comparative Cytotoxicity of Selected Mikania species using Brine Shrimp Lethality Bioassay and Sulforhodamine B (SRB) Assay
}

\author{
Rafeza Khatun ${ }^{1}$, Iffat Hasnin², Anamul Haque ${ }^{1}$ and Md. Aziz Abdur Rahman² \\ ${ }^{1}$ Department of Pharmacy, Comilla University, Comilla, Bangladesh \\ ${ }^{2}$ Department of Pharmacy, University of Rajshahi, Rajshahi, Bangladesh
}

(Received: September 25, 2020; Accepted: December 23, 2020; Published (web): January 28, 2021)

\begin{abstract}
This study aims to assess the comparative cytotoxic activity of the ethanolic extract of Mikania cordata (MC), Mikania micrantha (MM) and Mikania scandens (MS) (Family: Asteraceae) using brine shrimp lethality bioassay and colorimetric sulforhodamine B assay method. In SRB assay, A549 human lung carcinoma, SK-Mel-2 skin melanoma and B16F1 mouse melanoma cell lines were used. In brine shrimp assay, the $\mathrm{LC}_{50}$ for $\mathrm{MC}, \mathrm{MM}$, MS and vincristine were found to be $29.04,15.84,32.35$, and $1.2 \mu \mathrm{g} / \mathrm{ml}$, respectively. The results indicate that all the Mikania species showed moderate lethality against nauplii. In SRB assay, $50 \%$ cell growth inhibition concentration $\left(\mathrm{IC}_{50}\right)$ of $\mathrm{MC}, \mathrm{MM}$, MS and cisplatin against B16-F1 were 33, 15, 39 and $6.8 \mu \mathrm{g} / \mathrm{ml}$, respectively. Similar data were observed for other cell lines indicating moderate cytotoxicity of the extracts. Among the species, M. micrantha showed relatively potent cytotoxic effect followed by $M$. cordata and $M$. scandens. Similar data were observed for brine shrimp lethality bioassay and the results suggest that $M$. micrantha possesses highest cytotoxic potentials among all the species.
\end{abstract}

Key words: Mikania cordata, Mikania micrantha, Mikania scandens, Cytotoxicity, Brine shrimp lethality bioassay, SRB assay.

\section{Introduction}

Plants have been served as excellent sources of drug discovery since several decades due to less or no harmful side effects on health, and can be used in day-to-day life (Parekh and Chanda, 2007; Mohamed et al., 2012). In developing countries including Bangladesh, about $75 \%$ of the populations rely on different forms of traditional medicine for their primary health care (Bastos et al., 2008; Haque et al., 2018). To reveal the potential of folkloric reputed medicinal plants available in Bangladesh, we selected Mikania genus since the genus is the largest of its kind in the Eupatorieae (Family Asteraceae) tribe with around 400 species (Ferreira and Oliveira, 2010; Ittiyavirah and Sajid, 2013). Mikania species are well-known folkloric reputed plants used to treat cancer, fever, inflammation, rheumatism, oxidative stress, spasmolytic, respiratory diseases as well as snake bites (Hajra et al., 2010; Ittiyavirah and Sajid, 2013; Khatun et al., 2020). However, only a few of the species have been studied for biological activity.

A variety of biological activities such as antibacterial, antiviral, anti-inflammatory, antispasmodic, antioxidant, cytotoxic etc. are reported for Mikania species (Luciane et al., 2012; Hoult and Payá, 1996) and most of the reported activity are limited to Mikania micrantha and Mikania cordata though there are a lot of available species. In Bangladesh M. cordata, M. micrantha and M. scandens are widely available. Previously we reported comparative phenolic contents and antioxidant activity (Khatun et al., 2020),

Corresponding author: Md Aziz Abdur Rahman, E-mail: aziz2002@asia.com

DOI: https://doi.org/10.3329/bpj.v24i1.51630 
antimicrobial activity (Khatun et al., 2017a), and anti-inflammatory and thrombolytic activity (Khatun et al., 2017b) of these three species. A number of published research showed cytotoxic activity of various Mikania species including Mikania cordata (Ali et al., 2011), Mikania micrantha (Saikia et al., 2020) and Mikania scandens (Ahammed et al., 2020). However, comparative cytotoxicity evaluation of these species was not reported before. So, the current study was conducted to evaluate comparative cytotoxicity study of three commonly available Mikania species, Mikania cordata, Mikania micrantha and Mikania scandens using brine shrimp lethality bioassay and colorimetric sulforhodamine B assay.

\section{Materials and Methods}

Collection and identification of plants: The whole part of $M$. cordata (MC), M. micrantha (MM) and M. scandens (MS) were collected from Rajshahi (northern part of Bangladesh), Barisal (Southern part) and Kushtia (western part), respectively, during the month of August 2017 and were identified by Dr. AHM Mahbubur Rahman, associate professor and taxonomist, Department of Botany, University of Rajshahi, Bangladesh.

Extraction and fractionation: The plants labelled as MC, MM and MS were air dried for several days and then oven dried at $45^{\circ} \mathrm{C}$ for 24 hours. The dried plants were crushed separately into course powder. About $170 \mathrm{gm}$ powdered plant materials were taken separately in an amber-colored extraction bottle and were soaked with $70 \%$ ethanol $(90 \mathrm{~mL} \times 3$ times $)$ for 7 days with occasional shaking. The extracts were filtered through cotton and Whatman No. 1 filter, concentrated with rotary evaporator under reduced pressure at $45^{\circ} \mathrm{C}$ and preserved at $4{ }^{\circ} \mathrm{C}$. The percentage of MC, MM and MS extract (w/w) were $11.00 \%, 10.5 \%$ and $9.3 \%$, respectively (Khatun et al., 2020).

\section{Cytotoxicity assay:}

Brine shrimp lethality bioassay: The experiment was carried out by the method described by Meyer $e t$ al. (1982). In brief, Artemia salina Lech. (brine shrimp eggs) was allowed for 48 hours in simulated seawater to hatch and mature as nauplii (Larvae) at $25^{\circ} \mathrm{C}$. Serially diluted extracts from MC, MM and MS were added to the simulated sea-water $(5 \mathrm{~mL})$ containing 20 nauplii. $120 \mu \mathrm{l}$ of DMSO was added to each of the three remarked glass vials containing $5 \mathrm{ml}$ of simulated sea water and 20 shrimp nauplii to use as negative control group. After 24 hours incubation at $25{ }^{0} \mathrm{C}$, the number of survivors was counted. The $\mathrm{LC}_{50} \quad(50 \%$ lethal concentration, $\mu \mathrm{g} / \mathrm{ml})$ were determined from triplicate experiments. Different concentrations of vincristine sulfate were taken as positive control.

Cancer cell line cytotoxicity assay (SRB assay): Cytotoxicity was measured by SRB (colorimetric sulforhodamine B assay) method (Skehan et al., 1990) using human lung carcinoma (A549), skin melanoma (SK-Mel-2), and mouse melanoma (B16F1) cell line. Human lung cancer cell line A549, human melanoma SK-MEL-2, and mouse melanoma B16-F1 were collected from Korean Cell Line Bank (Chongno-gu, Seoul, Korea). Briefly, exponentially growing cells were harvested and suspended in the culture medium $(100 \mathrm{~mL}$, RPMI1640) in a 96-well plate. Following seeding density was used: $1 \times 10^{5}, 1 \times 10^{5}$, and $2 \times 10^{4}$ cells $/ \mathrm{ml}$ for A549, SK-MEL-2, and B16-F1, respectively. After 24 $\mathrm{h}$ incubation at $37{ }^{0} \mathrm{C}$ under humidified $5 \% \mathrm{CO}_{2}$, serially-diluted test solutions $(100 \mathrm{ml}$ in RPMI medium) were added to the wells and incubated further for $48 \mathrm{~h}$. The cells were fixed with $50 \%$ trichloroacetic acid and stained for $30 \mathrm{~min}$ with SRB solution. Unbound dye was removed by $1 \%$ acetic acid (four times) and protein-bound dye was then extracted with $10 \mathrm{mM}$ tris base $(\mathrm{pH} \mathrm{10.5)}$ for $5 \mathrm{~min}$. Optical density of the released dye was measured at $520 \mathrm{~nm}$ in a microplate reader (Tecan Sunrise microplate reader). The results were expressed in terms of $\mathrm{IC}_{50}$ value. Cisplatin was used as a reference.

Statistical analysis: All analyses were carried out in triplicates. Statistical comparisons were performed 
using Microsoft Excel, 2019. Mean values \pm S.D. were calculated for the parameters where applicable.

\section{Results and Discussion}

The ethanolic extract of $M$. cordata, $M$. micrantha, M. scandens were evaluated for lethality against brine shrimp nauplii (Meyer et al., 1982). The result of the lethality bioassay is shown in Table 1 where mortality rate varies with concentration of sample and was increased with increasing concentration of the sample. The median lethal concentration $\left(\mathrm{LC}_{50}\right.$ in $\mu \mathrm{g} / \mathrm{ml}$ ) was determined by extrapolation from graph and the values for $\mathrm{MC}$, MM, MS and standard vincristine sulfate were found to be $29.04,15.84,32.35$, and $1.2 \mu \mathrm{g} / \mathrm{ml}$, respectively. Compared to positive control, the results indicate that all the Mikania species showed moderate lethality against brine shrimp nauplii and the activity of $M$. micrantha is two times more than that of M. cordata and M. scandens (Figure 1A). Since, the brine shrimp lethality bioassay is a preliminary toxicity screening of plant extracts (Oberlies et al., 1998), the findings had the potential for further cytotoxicity investigation.

Table 1. Results of in-vitro brine shrimp lethality bioassay of various Mikania species.

\begin{tabular}{|c|c|c|c|c|c|}
\hline Extract & $\begin{array}{l}\text { Conc. } \\
(\mu \mathrm{g} / \mathrm{ml})\end{array}$ & $\log C$ & $\%$ of Mortality & $\begin{array}{c}\text { Probit value (From \% of } \\
\text { Mortality) }\end{array}$ & $\begin{array}{c}\mathrm{LC}_{50} \\
(\mu \mathrm{g} / \mathrm{ml})\end{array}$ \\
\hline \multirow[t]{8}{*}{ M. cordata } & 200 & 2.30 & 100 & & 29.04 \\
\hline & 100 & 2 & 90 & 6.28 & \\
\hline & 50 & 1.7 & 75 & 5.67 & \\
\hline & 25 & 1.4 & 25 & 4.33 & \\
\hline & 12.5 & 1.1 & 15 & 3.96 & \\
\hline & 6.25 & 0.8 & 10 & 3.72 & \\
\hline & 3.125 & 0.5 & 10 & 3.72 & \\
\hline & 1.56 & 0.1 & 2 & 2.95 & \\
\hline \multirow[t]{8}{*}{ M. micrantha } & 200 & 2.30 & 90 & 6.28 & 15.84 \\
\hline & 100 & 2 & 90 & 6.28 & \\
\hline & 50 & 1.7 & 75 & 5.67 & \\
\hline & 25 & 1.4 & 60 & 5.25 & \\
\hline & 12.5 & 1.1 & 40 & 4.75 & \\
\hline & 6.25 & 0.8 & 30 & 4.48 & \\
\hline & 3.125 & 0.5 & 10 & 3.72 & \\
\hline & 1.56 & 0.1 & 15 & 3.96 & \\
\hline \multirow[t]{8}{*}{ M. scandens } & 200 & 2.30 & 75 & 5.67 & 32.35 \\
\hline & 100 & 2 & 50 & 5 & \\
\hline & 50 & 1.7 & 60 & 5.25 & \\
\hline & 25 & 1.4 & 45 & 4.87 & \\
\hline & 12.5 & 1.1 & 40 & 4.75 & \\
\hline & 6.25 & 0.8 & 40 & 4.75 & \\
\hline & 3.125 & 0.5 & 30 & 4.48 & \\
\hline & 1.56 & 0.1 & 10 & 3.72 & \\
\hline
\end{tabular}

Data for standard vincristine sulfate $\left(\mathrm{IC}_{50} 1.2 \mu \mathrm{g} / \mathrm{ml}\right.$ ) is not shown in the table 


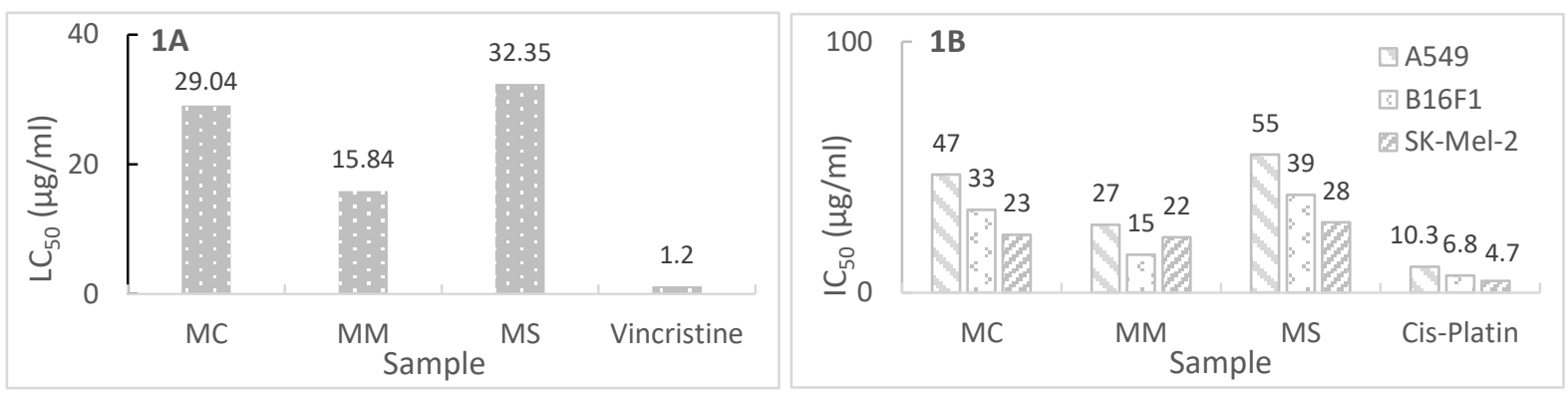

Figure 1. Comparison of (A) $\mathrm{LC}_{50}$ values from brine shrimp lethality bioassay and (B) $\mathrm{IC}_{50}$ values from SRB assay of extracts from M. cordata (MC), M. micrantha (MM) and M. scandens (MS).

Table 2. Results of in vitro cytotoxicity assay (SRB assay) of various Mikania species.

\begin{tabular}{lccc}
\hline Extract & \multicolumn{3}{c}{$\mathrm{IC}_{50}$ against cancer cell lines $(\mu \mathrm{g} / \mathrm{ml})$} \\
\cline { 2 - 4 } & $\mathrm{A} 549$ & $\mathrm{~B} 16 \mathrm{~F} 1$ & $\mathrm{SK}-\mathrm{Mel}-2$ \\
\cline { 2 - 4 } M. cordata & 47 & 33 & 23 \\
M. micrantha & 27 & 15 & 22 \\
M. scandens & 55 & 39 & 28 \\
Standard Cisplatin & 10.3 & 6.8 & 4.7 \\
\hline
\end{tabular}

The extracts were further evaluated for cytotoxicity against human lung cancer cell line A549, human melanoma SK-MEL-2, and mouse melanoma B16-F1 using SRB (colorimetric sulforhodamine B assay) method (Skehan et al., 1990). Results are shown in Table 2 and Figure 1B. The $\mathrm{IC}_{50}$ value of $\mathrm{MC}, \mathrm{MM}, \mathrm{MS}$ and standard Cisplatin against cancer cell lines A-549, B16-F1 and SK-MEL-2 were 47, 33 and $23 \mu \mathrm{g} / \mathrm{ml} ; 27,15$ and 22 $\mu \mathrm{g} / \mathrm{ml} ; 55,39$ and $28 \mu \mathrm{g} / \mathrm{ml}$, and $10.3,6.8$ and 4.7 $\mu \mathrm{g} / \mathrm{ml}$, respectively. The result demonstrated that $M$. micrantha showed potent cytotoxic effect followed by $M$. cordata and $M$. scandens. Similar data were observed for brine shrimp lethality bioassay and the results distinctly proved that $M$. micrantha might possess highest percentages of phytochemicals responsible for cytotoxic activity.

Mikania is an important plan genus commonly known as guaco found in the tropics of America and Asia (Ferreira and Oliveira, 2010). We have identified three commonly available species in Bangladesh: Mikania cordata, Mikania micrantha and Mikania scandens. Among these, Mikania cordata has been used in traditional herbal medicine for a long to treat various ailments including cancer by folklore people (Uy et al., 2015). Several reporters have also shown the cytotoxic activity of Mikania species (Saikia et al., 2020; Ahammed et al., 2020).

In our present study, we have evaluated lethality potentials of the selected species using brine shrimp lethality bioassay and cytotoxic potential using colorimetric sulforhodamine B assay. The shrimp lethality assay is a useful tool for preliminary evaluation of plant extract toxicity as well as for screening diverse compounds (Carballo et al., 2002), whereas SRB assay determines the inhibition of cell proliferation as well as cytotoxicity based on the measurement of cellular protein content (Bhagat et al., 2014). Though the extracts gave a higher $\mathrm{IC}_{50}$ value by $\mathrm{SRB}$ assay when compared to $\mathrm{LC}_{50}$ value by lethality bioassay, there was good correlation between $\mathrm{IC}_{50}$ and $\mathrm{LC}_{50}$ values. The activity of Mikania extracts followed a similar trend by both lethality bioassay and SRB assay where $M$. micrantha showed highest activity followed by other two species. 


\section{Conclusion}

The present observation established that the ethanolic extracts of $M$. cordata, M. micrantha and M. scandens have potent cytotoxic activity in vitro. The results validate the use of the plants in folkloric medicine and will provide scientific foundation for rational development and utilization of these plants. From the observation it was found that M. micrantha was more active than other species. Hence, the study can easily identify a more potent species that could be helpful for developing new leads. Further investigations in this direction can be attempted to find promising anti-cancer phytochemicals.

\section{Acknowledgments}

The authors are grateful to professor Dr Surk-Sik Moon, Natural Product Chemistry Lab, Department of Chemistry, Kongju National University, Korea for providing facility to conduct SRB assay and Dr A. H. M. Mahbubur Rahman, Associate Professor, Department of Botany, University of Rajshahi, Bangladesh for the identification of the plant samples.

\section{Reference}

Ahammed, K., Joardar, M.H.H., Islam, M.U., Yameen, M.B., Rahman, S.M. and Sharmin, R. 2020. Evaluation of nephroprotective and cytotoxic effect of ethanolic extract of Mikania scandens leaves by using alloxan-induced diabetic nephropathy mice. Clin. Phytoscience 6, 1-8.

Ali, M.S., Islam, M.S., Rahman, M.M., Islam, M.R., Sayeed, M.A. and Islam, M.R. 2011. Antibacterial and cytotoxic activity of ethanol extract of Mikania cordata (Burm. F.) BL Robinson leaves. J. Basic Clin. Pharm. 2, 103-107.

Bastos, G.N.T., Silveira, A.J.A., Salgado, C.G., PicançoDiniz, D.L.W. and Do-Nascimento, J.L.M. 2008. Physalis angulata extract exerts anti-inflammatory effects in rats by inhibiting different pathways. $J$. Ethnopharmacol. 118, 246-51.

Bhagat, J., Lobo, R., Kumar, N., Mathew, J.E. and Pai, A. 2014. Cytotoxic potential of Anisochilus carnosus (L.f.) wall and estimation of luteolin content by HPLC. BMC Complement Altern Med. 14, 421.
Carballo, J.L., Hernández-Inda, Z.L., Pérez, P. and GarcíaGrávalos, M.D. 2002. A comparison between two brine shrimp assays to detect in vitro cytotoxicity in marine natural products. BMC Biotec. 2, 17.

Ferreira, F.P. and Oliveira, D.C.R. 2010. New constituents from Mikania laevigata Shultz Bip. ex Baker. Tetrahedron Lett. 51, 6856-6859.

Hajra, S., Mehta, A., Pandey, P., John, J. and Mehta, P. 2010. Antibacterial property of crude ethanolic extract of Mikania micrantha. Asian J. Exp. Biol. Sci. 1, 166168.

Haque, M.I., Chowdhury, A., Shahjahan, M. and Harun, M. 2018. Traditional healing practices in rural Bangladesh: a qualitative investigation. $B M C$ Complement Altern Med. 18, 62.

Hoult, J.R.S. and Payá, M. 1996. Pharmacological and biochemical actions of simple coumarins: natural products with therapeutic potential. Gen Pharmacol. 27, 713-22.

Ittiyavirah, S.P. and Sajid, K.P. 2013. Antistress activity of Mikania micrantha Kunth roots in Wistar albino rats. J. Sci. Ind. Res. 2, 999-1005.

Khatun, R., Nasrin, L., Roy, S., Tantry, M. and Rahman, M.A.A. 2017a. Comparative antimicrobial evaluation of available Mikania species in Bangladesh. Int. J. Plant Res. 7, 36-38.

Khatun, R., Rashid, M., Alam, A.H.M.K., Lee, Y-I. and Rahman, M.A.A. 2020. Evaluation of comparative phenolic contents and antioxidant activity of Mikania species available in Bangladesh. Frontiers in Science 10, 1-6.

Khatun, R., Roy, S. and Rahman, M.A.A. 2017b. In vitro comparative evaluation of anti-inflammatory and thrombolytic activity of three Mikania species available in Bangladesh. J. Pharmacogn. Phytochem. 6, 1007-1011.

Luciane, C.R., Adriana, G., Joséli, S. and Sidnei, M. 2012. Genus Mikania: chemical composition and phytotherapeutical activity. Rev. Bras. Farmacogn. 22, 1384-1403.

Meyer, B.N., Ferrigni, N.R., Putnam, J.E., Jacobsen, L.B., Nichols, D.E. and McLaughlin, J.L. 1982. Brine shrimp: a convenient general bioassay for active plant constituents. Planta Med. 45, 31-34.

Mohamed, I.N., Shuid, A.N., Borhanuddin, B. and Fozi, N.F. 2012. The application of phytomedicine in modern drug development. Int. J. Herb. Plant Med. 1, $1-9$. 
Oberlies, N.H., Rogers, L.L., Martin, J.M. and McLaughlin, J.H. 1998. Cytotoxic and insecticidal constituents of the unripe fruit of Persea americana. $J$. Nat. Prod. 61, 781-85.

Parekh, J. and Chanda, S. 2007. Antibacterial and phytochemical studies on twelve species of Indian medicinal plants. Afr. J. Biomed. Res. 10, 175-181.

Saikia, S., Tamuli, K.J., Narzary, B., Banik, D. and Bordoloi, M. 2020. Chemical characterization, antimicrobial activity, and cytotoxic activity of Mikania micrantha Kunth flower essential oil from North East India. Chem. Pap. 74, 2515-2528.
Skehan, P., Storeng, R., Scudiero, D., Monks, A., McMahon, J., Vistica, D., Warren, J.T., Bokesch, H., Kenney, S. and Boyd, M.R.J. 1990. New colorimetric cytotoxicity assay for anticancer-drug screening. $J$. Natl. Cancer Inst. 82, 1107-1112.

Uy, T.G.C., Licuanan, A.M., Angeles, G.E.D., Bote, M.L.C.C., Macauyag, E.A.B., Hernandez, C. C. and Guzman-Genuino, R.M. 2015. Anti-cancer effect and mechanism of action of Mikania cordata plant extract on MCF-7 Human breast adenocarcinoma cells. Int. J. Cancer Res. 11, 80-92. 